\title{
Gacaca, Genocide, Genocide Ideology: The Violent Aftermaths of Transitional Justice in the New Rwanda
}

\author{
MARK ANTHONY GERAGHTY \\ Department of Anthropology, University College London
}

...we can invert Clausewitz's proposition and say that politics is the continuation of war by other means.

Michel Foucault (2003: I5)

That "mode of warfare" — or rather lawfare, the effort to conquer and control indigenous peoples by the coercive use of legal means-had many ... scripts. Most commonly noted among them was the creation of so-called customary law ... "the invention of tradition."

John Comaroff (200I: 306)

One of the twelve thousand Gacaca Court (Inkiko Gacaca) hearings held each week throughout Rwanda, at the height of their period of operation began by calling back before the court a man who had already been tried and sentenced just two weeks prior. Since the conclusion of his trial, the man's family were said to have committed an offence that justified re-opening his case for genocide. The President of the court initiated the proceedings by addressing those in attendance: 'There is a problem. We had sentenced Gahutu and the matter had finished. But we now have a problem relating to his wife, and also a problem with the people who went on to celebrate how they won (batsinze). The cries of celebration! They were showing off, mocking the misfortune (bagashinyagurira) of the victims. It caused us pain and we saw it necessary to 
return to that problem so that the citizens (abaturage) can speak about it.'

Although the man had been sentenced to five years of TIG (Travaux d'Intérêt Général, or 'works of public interest') — manual labor in state construction projects — the President here referred to him and his family as having 'won' the case. ${ }^{I}$ This was because Gahutu had avoided a lengthy prison term, which had become the expected outcome of Gacaca trials in this area, following his acquittal on one of the charges. However, since that trial's conclusion, the President was suggesting, the court had come to learn that Gahutu's family had celebrated the 'lenient' sentencing. This, according to the President, had caused further suffering to the "victims" (abahohotewe) in the case, the official "survivors" (abacitse ku icumu) of the “Genocide Against the Tutsi” (Jenoside Yakorewe Abatutsi). This, in turn, caused 'pain' to the Inyangamugayo, the officials authorized to preside over and decide Gacaca cases-already pointing to the great expansion in practice of the latter's authority and mandate, to seemingly that of 'protectors' of "genocide survivors." The court's decision to reopen the concluded case, like much of the practice of Gacaca, contravened the writ of the law that ostensibly governed these courts. However, it was further justified in the name of allowing the abaturage ('citizens'/'people') to speak, thereby invoking the official self-legitimating discourse of Gacaca as a mechanism of "grassroots democracy" aimed at delivering "Truth," "Justice," and "Reconciliation" for and by the people of Rwanda.

Inkiko Gacaca were specialized tribunals instituted by the Rwandan state in 200 I ostensibly to prosecute crimes of genocide committed between I October 1990 and 3I December 1994. They were solely concerned with crimes committed as part of the event that they helped to officially constitute as the "Genocide Against the Tutsi." They had no mandate to examine atrocities committed against ethnic Hutu by the former "guerrilla" forces—now the ruling Rwandan Patriotic Front (RPF) party—either during or after its campaign to capture the country during its I990-I994 "Liberation" war (Corey and Joireman 2004; Ingelaere 2016). The RPF was formed by descendants of those who had been exiled from the country, as the hitherto ruling "Tutsi" elite, by the 1959 "Hutu" "Revolution" 
(Impinduramatwara/Revolusiyo). This Revolution occurred on the eve of Independence from Belgian colonial rule, and was constituted by the successive regimes founded upon it as having overturned a "feudal" system of monarchical rule by the Tutsi "minority" to establish a "democratic" republic championing the rights of the Hutu as the demographic "majority." The RPF's "Liberation" or 'Victory' of I994, which founded the self-proclaimed "New Rwanda," has been narrated unofficially, by those who support it as much as those opposed, as having 'overturned' or 'defeated' the I959 Revolution.

Gacaca courts differed from Rwanda's conventional courts of law in that they claimed to allow the active participation of the local population in their operation (theoretically enabling all attendees to speak and ask questions of the accused); restricted recourse to representation by lawyers (requiring accused persons to defend themselves); and, in lieu of legally trained judges, authorized panels of selected local officials named Inyangamugayo to act as de-facto judges, prosecutors, and juries in an inquisitorial-styled system to pass sentences of up to life in prison. Inyangamugayo were chosen from among the 'ordinary people' (abaturage basanzwe) to preside over genocide cases in their own neighborhoods. Legally trained lawyers, judges, and local government officials were generally formally excluded from these positions. Inyangamugayo possessed no legal training or experience and their only required qualification was that they be literate and "thereby" able to understand the law. Each court was formally required to have at least five Inyangamugayo, with a maximum of nine, who were differentiated according to a hierarchy of positions, such as President, ranked Vice Presidents, and a Secretary. But in practice, court proceedings and judgments were dictated by a few powerful members, who were invariably (though secretly) members of the ruling RPF. ${ }^{2}$ Thus, via such reiterations of national-level structures and positions, these tribunals officially spoke for the people while acting as the state. After initial 'exploratory' and 'information gathering' phases, the courts began to conduct trials on a national scale by early 2007. And although they had virtually drawn to a close by August 2010 (and were officially declared over in 2012), according to official records they tried a staggering I.9 million cases, involving over a million defendants, with a 
conviction rate of 86 percent.

The name "gacaca" previously referred to a local mechanism for resolving disputes between neighbors, whether over land, theft, or other social conflicts (Reyntjens 1990). The word gacaca also referred to the area of 'short grass' where 'elder men' (abagabo) would gather to discuss such problems. The more recent institution of Inkiko Gacaca claimed its name in part by their often meeting in areas of open grass, but many courts were held under makeshift tarpaulin structures on the gravel yards adjacent to local government (Umurenge) offices, where there was a detention cell, or in school classrooms or community halls. The earlier forums of gacaca did not decide on serious crimes, such as killings, nor had they the power to imprison people. They operated according to different logics or practices than did the state penal institution charged with adjudicating crimes of genocide (Ingelaere 2016: I8ff.). By appropriating the name, however, the Rwandan state claimed that Inkiko Gacaca were rooted in precolonial Rwandan "tradition" (however "invented”; see Hobsbawm and Ranger 1983), and therefore represented a legitimate "Rwandan" solution to a "unique” Rwandan "post-genocide” context.

In addition to such claims for local cultural and historical particularity, Inkiko Gacaca's selflegitimating narrative framed itself as part of the internationally recognized genre of "peace-building" mechanisms known as "transitional justice" (Teitel 2008; Waldorf 2006). It thereby cited precedence for its establishment from politico-legal initiatives across a wide range of historical contexts, such as the "Truth and Reconciliation Commission" in South Africa (Wilson 200I), as well as those in Sierra Leone (Shaw, Waldorf, and Hazan 2010), Canada (Henderson and Wakeham 20I3), and Colombia. Jean and John Comaroff (20I2) have critically argued that such institutions of collective "truth-telling," which are used "to generate authoritative accounts of the past" though "a simulacra of legal procedures," involve both a fetishization of memory and a silencing of certain pasts. And despite heterogeneous logics, processes, and effects, such institutions have recently become an internationally recognized means for ritually demarcating the boundary between "new" political dispensations and those now officially "past" large-scale conflicts 
that inaugurated their rule (Mamdani 2000; Henderson and Wakeham 2013; Feldman 2015). This highlights how such institutions of peace-building and justice, and their forms of knowledge, are not external to conflicts but instead play a constitutive role within them (Merry and Coutin 20I4: I; Shaw, Waldorf, and Hazan 2010: 137). Indeed, such political processes have become a global citational form for performatively inscribing what Benjamin (I997[192I]) once referred to as the "necessary sanctioning" of the peace ceremony, marking the transition, not between violence and its end but rather between "lawfounding" and "law-preserving" forms of violence (Geraghty 2016). For no matter how violent "peacetime" is felt to be (e.g., Doughty 20I6:2I), all that may have been formerly recognized as "political" transgression henceforth comes to be officially re-inscribed more narrowly as "criminal" (see Moodie 2010), a political practice with longstanding liberal-imperial genealogies (Amin 1995; Foucault 2003). Which is to say that the political practices of violent aftermaths often have less to do with rendering conflict "post" than with establishing new self-legitimating narratives to render it less visible (Derrida 2002; cf. Perez 2008). Following a dominant neoliberal dynamic, the success of such institutions in masking their own politics (Shaw, Waldorf, and Hazan 2010; Merry and Coutin 2014), in part through the continual reiteration of a self-legitimating discourse of "human rights," is evident even in the vast academic literature that reproduces such political claims as "neutral" statements of fact, narrowing the space of critique to identifying external "corruptions" of otherwise universally legible and "genuine" “original” "aims" or "intent" (e.g., Ingelaere 2016, Doughty 2016).

Critically, for Derrida (2002), Benjamin's "law-founding" violence already necessarily entails its "preservation," for to maintain or stabilize the law, the violence upon which it is founded will have to continually repeat or re-inscribe itself in new forms and ways. Foucault similarly recognized that the unequal relation of forces achieved through war will re-inscribe itself throughout the discourses, practices, institutions, and wider structures of the new state of "peace" (2003: I5-I6). The term "violent aftermaths” seeks to invoke this very doubling of violence during the moment of its discursively 
constructed aftermath—its transformations, even as it reproduces itself in different registers, in its supposed wake. Recognition of this is subject to erasure by academic reiterations of self-legitimating political claims to the "post-conflict," the "post-genocide," the "post-colonial," or any other "end of history" narrative claiming absolute finality. Following Benjamin allows us to grasp what often eludes those blinded by (binary colonial) self-legitimating narratives (e.g., Slotta 2015: I3I): how the "peace-building" mechanisms of transitional justice, and the wider fetishization of law (Comaroff and Comaroff 20I2), are as essential to "liberal democratic" states as they are to their "authoritarian" others, the systems of law of all of which are constituted through violence. That is to say, the chronotope, or space-time, of violent aftermaths cannot be relegated to those "post-conflict" zones consigned to the "periphery" of Western liberal democracies (Taussig I989), but constitutes the very grounds of a shared global history (see Benjamin 2006: 392), where the "(post-)genocide" statuses of states such as Australia, Canada, or the United States (Madley 2016), continue to be subject to erasure by the victors' self-legitimating narratives, and repressed or non-generated guilt (see Adorno 2010) is thereby often subject to uncanny returns (Lepselter 2016).

Shoshana Felman (2002) traces the establishment of legal proceedings as a theatrical mechanism for inscribing responsibility for the traumas of war to the Nuremberg trials that followed Europe's most catastrophic episode of war and annihilation in the mid-twentieth century. From this perspective, the Rwandan state's deployment of Gacaca Courts can be seen, contra its self-legitimating discourse, not as a local Rwandan model but one that is preeminently European modernist - that is, colonial (see the opening epigraph by John Comaroff). And indeed, as has been noted elsewhere (Shaw, Waldorf, and Hazan 20I0; Theidon 20I4), the Western tradition of "truth telling" (Nietzsche I998; Foucault 20I4), among other transitional justice conventions, was frequently at odds in Gacaca with local understandings (Ingelaere 2016). For example, relatives of genocide victims I spoke to, who avoided these courts, often referred to public "confessions" to killings as unbearable 'heroic boastings' (ibyivugo-self-praise recitals by warriors 
in times past [see Kagame 1969: I5ff.]) by their enemies. The deeper genealogy of such courts in this region, and throughout the colonial world, stretches back to the imposition of the liberal-imperial state and, notably in Africa, its bifurcation of "law" from (equally colonially constructed) "custom" (Chanock 1985; Fields 1985) or "invented tradition" (Hobsbawm and Ranger 1983; Comaroff 200I). And the concern of colonial law and courts with "preventing conflict" and forging calculability and systematizing commensurabilities furnishes the historical terrain for a genealogy of the transitional justice mechanisms of the neoliberal era of colonial capitalism.

All of this does not preclude other genealogies. Western-centric readings of Rwandan history narrowly through the narrative of the Holocaust have curtailed conceptual and methodological investigations of Gacaca and its construction of the crime of genocide. The precedents that may also become evident in the account that follows, but have been ignored in most writings about Gacaca, ${ }^{3}$ point to the long history of public "show trials" in communist contexts (Hodos 1987; Viola 2017). That history would not have been lost on the RPF, which has long inscribed itself within a transnational network of Maoist "guerrilla" liberation movements across Africa and beyond (Clapham 1998). The RPF's use of public "confessions" (Whyte 1974: 74ff) and its parading of "criminals" in "legal" spectacles of sovereign power extended beyond Gacaca. Even people accused of non-genocide crimes have been paraded in front of the media, prior to their trials (see Mwambari 2019:10). RPF members frequently cited their genealogical links to communist histories in their Maoist (Ingando/Itorero) "re-education" camps, that target not just their designated "cadres" but the population as a whole (Geraghty 2016). Other neglected genealogies include the local discursive practices I focus on here first, following Siegel (2006: 3), such as the hierarchical dynamics of the 'dominant'/'victorious' versus the 'dominated'/'defeated' which pervade local socio-political relations in Rwanda. All these genealogies informed the multifarious and discontinuous mediations of the global, national, and local discourses, practices, and institutions that constituted Gacaca. Though many scholars have sought to construct normative boundaries between the typological ideals 
of "trials" and "truth commissions" (Humphrey 2003), in contrast to some well-known cases that have gone under the latter name, Gacaca Courts had the power to imprison people and with sentences of up to life. Given the deprivations of Rwanda's prisons, even sentences of fifteen years were looked upon during the early days of Gacaca trials, by those seeking to imprison as well as those being imprisoned, as equivalent to a death sentence in both the social and corporeal senses. However, certain constraints were placed upon the ability of these courts to punish indiscriminately. One was the official policy of "Reconciliation," which for many who identified with the New Rwanda meant that by the time Gacaca was inaugurated it was, in general, no longer standard practice to exact 'revenge,' as was usually desired, by killing those made to stand in for the perpetrators (Prunier 2009; Geraghty 2016: 359-7I). For those involved in organizing Gacaca trials, "Reconciliation" also meant that it was not possible (and the state media often pointed out, not economically sustainable) to imprison the entire Hutu population, however much such a fantasy structured the desire of many who identified with the "new" state. These resented restrictions were widely understood to be due to "observation," however limited, by the "international community" upon which the Rwandan government directly depended for over 50 percent of its annual budget (Reyntjens 20I3: I34). Large sums of international money were also donated directly to Gacaca, but since Inyangamugayo were not paid for their services, that money went primarily to the paid government officials at the National Service of Gacaca Courts, which claimed to "sensitize," "monitor," and "advise" the "independently" operating courts while maintaining records of their caseloads and verdicts. Documenting a certain number of "acquittals" became part of the process of internationally legitimizing these courts. Those organizing Gacaca locally enthusiastically would call "acquittals" to my attention, however few there were, narrating them as a sign fetishized by Euro-American foreigners (Abazungu) as a hallmark of "justice."

This article departs from much of the existing literature on Gacaca by not simply taking the object of these courts at face-value and instead investigating precisely how they came to constitute the crime of genocide. Here I do not approach the work of Gacaca reductively in terms of its written laws or explicitly 
professed "aims," the seemingly self-evident terms of its self-legitimating narrative. Instead, I examine the logics inscribed by its situated practice, building upon the more critically researched scholarship on these courts (e.g., Chakravarty 2016; Doughty 2016; Ingelaere 2016). I pursue these questions not at the level of ungrounded generality or simple generalizability, but rather through the irreducible singularities of the trials themselves. I read an emergent discourse by attending to the time and place of a single hearing: the retrial of Gahutu. The argument I make for a wider discursive movement beyond this particular case recognizes the essential possibility that the event, however singular, is structured through its necessary repetitions (always with difference), whether the trace of those past or to come, and at the same time any (iterative) generality, or iterability, is constituted solely upon these differential and discontinuous instantiations (Derrida 1977). This essential iterability ruptures any simple empirical-structural divide and precludes any self-same generality that could be bounded with certainty, since it can only appear or be repeated as other than itself.

Without dismissing the irreducible contingency of beginning my analyses of Gacaca with this trial, my reading of this singular case is informed by my weekly attendance at Gacaca hearings, continuously within the same neighborhood and intermittently in other areas, over three and a half years from 2007 to 2010. This trial's significance, for my purposes, lies in something that was at once peculiar to it and yet thereby proved to be especially revealing of the operations of these courts more widely: a singular "excess" which to a generalizing gaze may be dismissed as an "aberration" or marginal element, yet demonstrates a critical dynamic at play throughout Gacaca's broader practice. That this case initially involved an acquittal for a genocide charge, which the same court overturned just two weeks later, following the alleged improper conduct of the family of the accused, highlights a hermeneutic that I argue reiterated more widely throughout Gacaca's practice. This was the role that a particular iteration of "genocide ideology" had at the local level in constituting the crime of genocide-or jenoside, a newly coined term in Kinyarwanda, as a transliteration of the French word "génocide" — thereby shaping the practices of these courts in a 
determinate way. To begin to examine this, we need to return to the words of the President of the court at the opening of Gahutu's retrial.

According to the President, the act(s) of celebrating, which justified Gahutu be retried, constituted gushinyagura. Gushinyagura was often narrated to me as an act of maliciously mocking the misfortune of others to inflict further pain upon them. To ask a mother sitting alone, knowing that her children had died, "Where are your children? Are they away at school?" would be an act of gushinyagura. Though virtually everyone I asked agreed that gushinyagura was a morally reprehensible act, it was not at the time of this trial specifically prohibited in law, either in Gacaca or the regular courts. Previously, gushinyagura had not followed ethnic boundaries as an act that could be committed by any 'evil' (ubugome) person. However, in the New Rwanda (uRwanda Rushyashya), forged through the event constituted and officially named since 2008 as the "Genocide Against the Tutsi," the recognition of past traumatic suffering was granted only to ethnic Tutsi, and gushinyagura came to be increasingly translated into "genocide ideology" (ingengabitekerezo ya jenoside)—a crime leveled almost exclusively against ethnic Hutu (Geraghty 2016). When the law against genocide ideology formally entered the statute books in 2008, gushinyagura was listed as one of its possible characteristics, though independent of ethnicity it was not legally prohibited. Importantly, both violations depended upon a locally understood motivation of 'malicious intent.'

According to the writ of the law, the crime of genocide ideology prosecuted "thoughts," revealed through speech, writings, or other actions, "aimed" at inciting ethnic hatred and "thereby" threatening a recurrence of genocide. Gacaca Courts, however, as specialized genocide tribunals, technically had no jurisdiction over crimes of genocide ideology, and such prosecutions were supposed to be taken to Rwanda's regular courts. Furthermore, legally, acts and utterances could only could be prosecuted as genocide ideology, or the related crimes of "divisionism" or "trivializing genocide," if they had occurred subsequent to the enactment of the laws proscribing these crimes, which was from 200I onward. By contrast, crimes of genocide prosecuted through Gacaca were legally confined to acts committed between 
1990 and 1994. However, imprisonments for crimes of genocide ideology were initiated at the very same time that Gacaca began to operate and became one of its critical conditions of possibility, dictating what could be said and what voices would be heard in a forum officially promoted as 'enabling the ordinary people to speak.'

The practice of Gacaca, as we will see, provided a critical public forum wherein "ingengabitekerezo ya jenoside" (genocide ideology), a phrase comprised of words newly coined by the state, came to be negotiated in terms of local categories that had long structured ordinary, or non-ethnic, conflicts between neighbors. These related to 'poisoning' or 'witchcraft' (uburozi), and through its practice the institution of Gacaca came to operate as a kind of witch-hunter, pursuing those to be purged from the New Rwanda. The new witch, I argue, was not the perpetrator of crimes committed in I994, but rather those divined to be inhabited in the present by a popularly understood "genocide ideology," the divined presence of which proved one's capability — past, present, or future— to commit genocide. In this way, genocide (jenoside) was constituted as a crime whose contours extended far beyond the boundaries of any international legal definition to include a wide range of acts, utterances, and inner states whose criminal nature could not be known in advance but only post-factum, when detected by these courts. One of the primary effects of these courts was that, rather than working to demarcate the boundaries of this newly identified crime, they came to render them, for the general population, all the more elusive.

From the point of view of the adjudicators, they could be said to have been acting upon their intuitions about the communicative nature of the signifying phenomena they were analyzing, even if they were unable to locate in them determinate violations of particular laws. Their processes of "intuition," however, rather than being based on any certainty shared throughout the neighborhood, were excessive and subject to a paranoid hermeneutics (see Hofstadter 1965; Sedgwick 2003), which extended through all levels of the state's 'war' against genocide ideology (Geraghty 2016). It led them to project an interiority within 'others' that was constantly on the verge of erupting into insurrectionary or law-founding violence 
(Benjamin 1997), threatening the very existence of the "new" state.

From the perspective of the state, the ambiguity of the crime of genocide proved to be a highly productive modus operandi-an effective means of exercising power locally, even if it was also driven by that which exceeded the political and eventually came to undermine the interests of the state. It increased the terror of these courts among the citizenry, requiring all who wished to avoid being called before them to adopt practices of self-surveillance of their quotidian acts and utterances-though these could never prove to be sufficient ${ }^{4}$ — in an effort to avoid betraying signs that could potentially mark them as inhabited by genocide ideology and thereby capable and guilty of genocide. This was not the guilt of those who sought to hide their complicity in acts widely recognized as heinous, but rather a new realization brought about by the sovereign spectacle of Gacaca that the wide range of signs now authorized as evidence leading to the weekly imprisonment of one's neighbors were states, acts, and utterances so diffuse they could potentially incriminate any "Hutu." That is, through the theatrical process of the trial, "Hutu" itself was transformed into a negative political category. And through its practice, Gacaca came to effect the realization throughout the vast population of all those who knew they could easily be marked "Hutu" that the crime of "genocide" could potentially inhabit any and perhaps even all of them, thereby producing a generalized fear and pervasive silence. $^{5}$

\section{THE TRIALS OF GAHUTU}

Gahutu had originally been tried for two counts of genocide. The first was a crime of speech, his having been accused of verbally 'persecuting' (gutoteza) one of 'the hunted' (uwahigwaga). The latter term was commonly used in Gacaca to refer to those targeted by the Genocide, in lieu of naming the ethnicity of those inhabiting the officially "post-ethnic" space-time of the New Rwanda-a practice subject to forced avoidance at this time (see Geraghty 2016). Gahutu was accused by the victim of his speech, who was a 
long-term neighbor and previously a friend of his family. In court, this woman testified that one day during the Genocide when she was visiting Gahutu's wife, Gahutu returned home and began to utter menacing words. He declared that things were going to become worse, and as one of the hunted she felt threatened and feared for her life. Gahutu and his wife argued in court that his words were 'not intended to intimidate their neighbor but were an expression of despair following the news that Gahutu's brother's son had been killed by shellfire. For the court, however, the neighbor's status as one of 'the hunted,' that is, as a Tutsi victim, not only determined that her version be recognized as the "truth" but also overdetermined the significance of his utterance. According to a logic we are about to examine, it was deemed an act possessed by a certain 'intent,' or internally located compulsion to menace Tutsi, and was thereby revealed to constitute genocide. ${ }^{6}$

Several factors seem to have allowed Gahutu to avoid a lengthy prison sentence. The most important, I would argue, was the way he conducted himself in court. Perhaps out of fear, he rarely spoke, doing so only when the Inyangamugayo directly questioned him, and he generally sat before the court with his head bowed in silence. These were all potential signs of humility and repentance. To the court, this man posed little threat. That is, as we will come to examine, his utterances and bodily comportment exhibited few signs that he was presently possessed by any resistance to the court or (metonymically) by any 'hatred' towards Tutsi in general that could be read as signs of genocide ideology. By contrast, Gahutu's wife, who in keeping with the Rwandan custom of teknonymy we will name Mama Ishmail, not only knew how to speak but proved herself a formidable defender of her husband and family in court. As a result, during the first trial the Inyangamugayo ordered that she be forcibly removed from the court by the state's extraconstitutional militia, the Local Defense Forces, armed with AK-47s, who were charged with "security" during Gacaca trials. The court had continually warned her, contra the writ of the law, that if she persisted in defending her husband she herself would be convicted for 'lying,' a threat they later carried out at the end of the retrial when they sentenced her to six months imprisonment. With his wife locked up in a 
detention cell, Gahutu bowed to pressure and 'asked for a pardon' for the words he had said to his neighbor's wife. This earned him a reduced sentence-though not in accordance with the writ of the lawand also appeared to enable his acquittal for the second crime he was accused of. For his "confession" to the first crime was also a sign that he now no longer continued to hold any 'ill-will' toward his Tutsi $\operatorname{victim}(\mathrm{s})$.

The second crime that Gahutu was accused but not convicted of during the first trial concerned the death of his neighbor's child. As it was narrated by all sides during the trial, when he and his family were fleeing the country in July 1994 (along with millions of others), as the RPF rebel forces were on the verge of capturing power, they took with them the child of their neighbors, who they had planned to accompany into exile. When their neighbors belatedly reversed their decision to undertake the arduous journey, since the mother had just given birth to a second child, Gahutu's family had already left with the first child, a young girl who subsequently died along the way. According to Gahutu's family, the child succumbed from diarrhea. For over a decade, her family remained silent and according to neighbors testifying in court appeared to have accepted her death as a tragic instance of 'misfortune' (ibyago) — a death not due to any human agency or malevolence. According to all narratives presented in court, the two families, at least publicly, had continued to live together as close 'relatives' (umuvandimwe/abavandimwe)_as longstanding good neighbors_-seemingly as before. However, some thirteen years later, in the late stages of the Gacaca courts process, the death of this child came to be raised as a case of genocide.

The mother, who we will call Mama Hassan, had given birth to the child who died before she met her current husband, a man who had long considered Gahutu as his 'brother' (umuvandimwe, baranywanye) according to a dominant local discourse connecting those who shared prolonged spatial and social intimacy. Although previously publicly unknown, when the case was raised in Gacaca, Mama Hassan declared that the father of her first child was a man who had left the area to go 'fight for the RPF.' That was to indirectly say that he was a Tutsi, and though no other detail about him was ever revealed, the 
custom of patriliny stipulated that he had bequeathed his ethnicity ( ubwoko) to his child. What gave the mother's story credibility in Gacaca was that she herself was recognized as a "survivor" of the Genocide. This was relevant not for determining the child's ethnicity but rather for accepting her word as "truth" in a forum that privileged, above all others, the word of survivors who sought to accuse. The ethnicity of the child's stepfather, who was locally recognized as a Hutu, was made irrelevant. And since Gahutu and his family had already been inscribed as ethnically Hutu during the pretrial process of accusation, covert investigation, and identification, the case came to be constituted as one of Hutu killing Tutsi, that is, inscribed within the narrative of the "Genocide Against the Tutsi." It was this child's death that Gahutu's retrial came to focus on.

\section{Misfortune, HATRED, GENOCIDE IDEOLOGY}

Those who sought Gahutu's conviction worked to undermine the explanation that the child's death had been the result of 'misfortune.' Madame Ndabateze, the neighbor who had accused Gahutu of verbally persecuting her, argued in court that when he and his wife went into exile, they also took two children of their own who were just as young as the one who died. So why had they managed to bring back safely their own children and not the one who did not belong to them? Though there was a local idiom for negative chance occurrences—namely, 'misfortune' (ibyago), or the transliterated French term 'accident' (agisida)— it was argued that this was not sufficient to explain such a death. The vociferous group who led the accusations in court suggested that another force, variously named, was at work. The shifting nature of attempts to characterize that which would render this death "genocide" (jenoside) was in part an index of the recent introduction of this foreign-derived term in Rwanda and the on-going process of local attempts to make it meaningful.

One category that continually appeared was that of a certain 'hatred' (urwango), which those who 
spoke to defend Gahutu were at pains to stress that neither he nor his family possessed. As all the witnesses called by both sides testified that Gahutu's wife and other female family members had carried the child on their backs throughout the journey into exile, it was suggested that this showed that they had borne no 'hatred' toward her. Had they wanted to kill her, it was even initially suggested by the President, they would have done so earlier rather than after carrying her so far. Among the first to challenge this narrative was a 'young man' (umusore) the son of Madame Ndabateze. As was common in Gacaca and elsewhere, his focus was on explicating the insidious logic of the crime, the necessary interior state considered its 'driving force': 'That old man [Gahutu] told them [those attending the first trial] he had rage (umujinya) because his brother's child was hit by a rocket, that that is the reason he said those words [which Gahutu was convicted of saying to this man's mother]. Then he left with the Tutsi child. The Cockroaches (Inyenzi) are shooting them! Can you carry that child on your back?'

Gahutu had just lost a child, the son of his brother, whose death was haunted by an unspeakable absence. He had been killed by RPF rebels who were shelling even residential areas in their campaign to capture the country. Though the speaker here partially reveals this tabooed topic, he only invokes it sufficiently to ascribe an ethnic character to Gahutu's internal state, which is then fully revealed when linked to the words he was already convicted of, persecuting one of 'the hunted.' These words were driven by an internal 'fury' that exceeded reasonable (non-ethnic) response to personal loss.

Next, Gahutu is narrated as having fled with a Tutsi child. For the first time in the trial an ethnic label was explicitly used. What had hitherto been unspeakable is starkly announced to conjure for the court, with maximal affect, the ethnic nature of the crime. Both the child and the family of the accused are constituted as opposing social types, and the case is now one of an innocent Tutsi victim and a thereby aggressive Hutu perpetrator. This family of fleeing Hutus are being fired upon by the approaching rebel forces, identified as 'Cockroaches.' Violently inserting this term of violence into the narrative, the speaker invokes the extremist discourses of those who spearheaded the I994 extermination campaign against Tutsi. 
Through this virulent anti-Tutsi discourse, the speaker voices the internal state of the accused, and ascribes it the same character as the most active perpetrators of the "Genocide Against the Tutsi." He thereby conjures a collective "Hutu" "mentality," or criminal state of interiority. That the 'Cockroaches' are shooting at 'them' now is revealed as referring not simply to the accused's family but to all Hutu perpetrators of the Genocide who (reiterating an unofficial yet popular RPF discourse) are fleeing the country precisely to escape their crimes. It now becomes untenable to claim that the family of the accused acted like 'good neighbors' or 'family' by carrying that Tutsi child.

Next to speak was another young man, also a relative of Madame Ndabateze, with whom he lived as a 'son.' Like the previous speaker, however, he did not identify himself as related to any of those accusing Gahutu, nor did any of these very vocal family members sit next to one another in court. They thereby projected an image that they formed part of a broad consensus of public opinion, for any outside observers unfamiliar with local dynamics, such as researchers or even those officials from the national level occasionally sent to 'monitor' trials. Like his 'brother' who spoke before him, this man was an active participant in local meetings of IBUKA, the RPF-infiltrated organization representing genocide survivors nationally. He began with what now, following the insertion of the term 'Cockroach' into the narrative, for the first time is explicitly named as the 'genocide ideology' of Gahutu : 'For me, the way I have seen these things, I see you [the court] can halt ideology (ingengabitekerezo).... When I heard the reason why he got summonsed the second time I was shocked. Within that, there is a serious crime which deserves to be punished by the law.'

This, we should note, was the voicing of a state discourse that constructed genocide ideology as dangerously contagious (see Geraghty 2016). It was also a reiteration of a demand by genocide survivor activists that Gacaca courts punish this crime despite having no legal jurisdiction over it. This formally unschooled young man's use of the recently coined word 'ideology' (ingengabitekerezo), which at this moment still had not gained much currency amongst 'ordinary villagers' (abaturage), as opposed to political 
elites, suggested that he, like his brother, had rehearsed what to say with those who secretly organized Gacaca trials in meetings in homes and bars prior to hearings, something I was able to witness myself after a number of years in the neighborhood. The acts or utterances that the President deemed gushinyagura are now translated, via co-reference, into genocide ideology, which at this time was the subject of daily warnings by national leaders and the media. The young man then went on to reiterate the narrative his brother had introduced, explicating the criminal interior state, while continually repeating, to great incendiary affect, that for Gahutu the child was of the enemy 'Cockroach.'

In this narrative, the key piece of evidence unlocking guilt for the death of the child is the charge from the first trial, which Gahutu had already been found guilty of, that he had uttered menacing words to one of the hunted. The two crimes become symptoms of a singular, perduring, and ethnically motivated, internal state: a shared Hutu mentality or affect of rage intent on menacing innocent Tutsi, a criminal interiority that interdiscursively sutures these acts as their immanent cause. When then tied to the presentday act of gushinyagura, despite their great disparity across time and space and the differences between their alleged victims and perpetrators, all three "crimes" are posed as disparate manifestations of a popularly understood genocidal ideology. The force of this narrative was that it linked the act(s) of 'mocking the misfortune' of the victims, which had outraged the President, to the death of the child, about which the President had shown ambivalence by originally acquitting the accused, as well as to the genocidal act of verbal persecution that this court had already found Gahutu guilty of.

This narrative also drew its persuasive force from the way it enabled a crime that was previously 'concealed' to be revealed, its former invisibility being a hallmark of its 'truth.' The two crimes of speech now acted as 'evidence/signs' (ibimenyetso) for that which made possible the previously invisible crime of killing. This interpretative mode was common throughout wider Rwandan society, and in this case was a common focus of fascination in the constant repetitions of this narrative beyond the trial by more senior figures in the neighborhood, including those who likely helped to formulate it. It was thus informed by a 
dominant local hermeneutic that positioned 'truth' or 'reality' as something always concealed, hidden deep beneath surface appearances. Within this commonplace practice of suspicion, surfaces could index truths, but they always had to be 'deeply analyzed' (gusesengura) to unlock their hidden meanings. Surfaces, that is, were always potentially uncanny: seemingly ordinary appearances potentially concealed alarming threats, thereby producing intensified forms of distrust and suspicion.

Quite some time after these two young men had spoken, Gahutu used the first opportunity granted him to speak, not to respond to the question he was asked but to return to that word that had inscribed an entire history of traumatic violence upon his relationship with the dead child.

Gahutu: But there is a word someone mentioned, saying that I left with a young baby. I didn't think/know about those things of 'Cockroach.' This person, when we were going to ask for marriage, we met her at her home, she already had that child. We went to ask for a person, I didn't think/know about that we were going to ask for a 'Cockroach.'

President: What if you knew it?

Gahutu: They gave us a bride.

President: What if you knew it?

Gahutu: No, it is because he said that 'You were carrying a Cockroach child,' but she wasn't a Cockroach, in my heart she wasn't a Cockroach, she was a person like others.

Speaking as the 'brother' of Mama Hassan's husband ('they gave us a bride'), Gahutu tries here to protest that they were not thinking of the mother and child as ethnic enemies but as family. His internal state ('in my heart') was not one of hatred or malevolence but rather of familial affection.

Ignoring his claims of affinity, the President instead took the opportunity to press Gahutu on the issue that he had not known (rather than had not been thinking) that the child was a Tutsi. From the viewpoint of a Western observer, one of the major contradictions that arose during the trial was that the mother 
insisted that neither Gahutu, nor anyone else, not even her own husband, had known the identity of the father of her first child. One would expect this admission would invalidate the genocide case against Gahutu since he could not have killed the child for being a Tutsi if he had not known her ethnic identity. Yet, the court never granted that much significance. Here, we can see why this should be the case. In repeatedly asking the hypothetical question, 'What if you knew?' the President was rhetorically asking Gahutu whether he was not possessed by a certain genocide ideology, a virulent hatred or desire to menace Tutsi, and therefore would have killed that child had he but known she was a Tutsi. The President's insistence reveals what appears to us to be an unusual focus for the court, by demonstrating it was less concerned with whether Gahutu actually knew the child was a Tutsi and thus with whether he actually killed her. Instead, it was focused on whether he was possessed by a certain potentiality—which "genocide ideology" would only be one possible and recent name for — that would have made him capable of killing that child even if he did not actually kill her. For it was possible that, even if he did not actually kill her, this could have merely been due to a contingent factor, that he did not know that she was a Tutsi. The court, like the two accusing young men, was interested in the element of necessity-the 'driving force' behind any potential or possible crime, regardless of whether or not the crime was committed. It was the necessary capability of killing that made one guilty of genocide. And evidence for such a capacity could be detected in the present-day, or even future acts or utterances of suspects, or even members of their families. The crime of genocide was to be possessed by such a lethal force, even if its possibility, due to contingent reasons, had not been actualized. Genocide was a temporally unchanging and ever-present, lethal capacity to menace Tutsi. 


\section{DIVINATION, EVIL, WITCHCRAFT}

Genocide ideology is a curse (umuvumo) which should be fought by everyone.

Imvaho Nshya (Rwandan government newspaper), July 2004

During the retrial, the mother was asked why she had not reported the death of her child earlier, during the Gacaca 'Information Gathering' period. She explained her 'silence' as due to possessing 'little strength' (intege nkeya), and then addressed what belatedly brought her to raise the issue: 'Where things started, they started with that child, my son, called Hassan. So he.... Because.... But he told them about it. He told them that 'for me, because of the anger your children caused me, I immediately saw that, even my sister, what you must have done to her so that she died."

She was impelled to bring the case before Gacaca because of her son, who forced the issue by declaring to their neighbors that, because of the way their children treated him, he came to realize that they-the parents-had killed his sister all those years ago. Hassan had been a newborn infant at the time of his sister's death and so had no recollection of the events surrounding it. As Gahutu's daughters also had been very young children in 1994, he was not claiming that it was they who brought about his sister's death, but rather their parents, with whom they shared a certain capacity to inflict not only anger but even death.

According to the neighbors I asked, Hassan's falling out with Gahutu's daughters was of the mundane sort between adolescents. However, out of the anger they caused him, he came to see something in them that they could not control, and that brought to his mind something else, namely, the death of his sister. Hassan's reported words portray him as innocent of anything that could have warranted his becoming the 'victim' of Gahutu's daughters. Their actions are positioned as having come to him unexpectedly, beyond the bounds of quotidian reciprocity, as an accident, as it were, or as Siegel (2006) has theorized it, as a Derridean "pure gift." "The accident which occurs 'for no reason' and affects my life, comes, like the [pure] gift ... from nowhere," Siegel writes, "as one cannot account for its origins” (ibid.: 9, 7). In Mama 
Hassan's narrative, this experience made Hassan confront a limit, a space of non-meaning, foreign to the forms of recognition of quotidian reciprocity, an effect of which is that it brings to mind another moment of unrecuperated negativity, namely, the death of his sister. As Siegel notes, at such moments one may experience "trauma." Or, alternatively, through the naming of that which cannot be recognized, one may take the route of magic: "In the crucial moments of magic, one recognizes that one cannot recognize, that events are linked to each other in ways that seem to reveal something one cannot grasp” (ibid.: 79). Though neither Hassan nor his mother explicitly named the foreign power, which they accidentally came to feel that their hitherto seemingly ordinary neighbors possessed or were possessed by, rather than their narrative being structured by the repetitions associated with the psychoanalytic account of trauma, they appeared to have taken the path of the attempted domestication of the pure gift through the process of its naming. For as soon as the mother finished speaking, the President, who appeared to understand exactly what she was talking about, responded not by questioning but affirming what she had said. He explicitly summoned its culturally sanctioned name: 'evil' (ubugome), a purely destructive, anti-social force often narrated as the driving force behind 'witchcraft.' As Siegel notes, following Mauss and Kant, "At this point, a term heterogeneous to all judgment appears" (ibid.: 76). Such a term "accounts for linkages where otherwise there is no accountability" (ibid.: 79).

In his mother's narrative, Hassan's words are portrayed as originating neither from her own subjectivity — her deeply buried suspicions of her neighbors—or from his—his desire for revenge against the family of the children who caused him so much anger. Rather, they are but the effect of the negative experience that befell him like an accident. Despite the fact that he was but an infant at the time of his sister's death and could claim no direct sensory experience of what happened to her, something that has rendered his recent insight all the more significant, he comes to see what she herself could not. His estranged words, like an oracle, act to furnish the magical copula (ibid.: 84). They connect what otherwise could not be connected in a way that is felt to be meaningful, even if not fully explicable, and more 
significant than the mother's personal suspicions wracked by uncertainty. Even in reporting the crime, she is unable to find her own words ('So he... Because... But he told them...') and so reports those of her son, as if delivering the verdict of an oracle. Speaking through this third person, her words attain a "narrative voice" (Blanchot 198I; Siegel 2006: 88ff) and give her the 'strength' and authority to speak that she previously lacked. Such magical modes of divination were neither rejected nor questioned by the court but instead prompted the President to call others to also testify about how they came to suspect the evil committed by Gahutu’s family.

The next person to testify in court was Umuhoza, a female relative of Mama Hassan's husband, who was well known in the neighborhood to have had a conflict with Mama Ishmail. Since Umuhoza had come to live with Mama Hassan and her husband at a young age, she was raised as one of their children. She told the court that what first brought her to realize that Gahutu's family had committed a crime was an event tied to the accidental death of her own child a decade or so after the 1994 Genocide:

Umuhoza: That one, Mama Ishmail, she usually, really, one time she told this one [Mama Hassan] that I said it was them [Mama Hassan's family] who bewitched (bandogeye) my child. So that one [Mama Ishmail], she made real conflicts between us [Mama Hassan and I]. I spent, I spent almost, I spent four years without going home, and we didn't talk to each other. So, it came to be seen that that problem is what caused those things....

President: Yes. Continue....

Umuhoza: So, then I said, so maybe in order for that one, Mama Ishmail, to say that word that they bewitched us [i.e., a member of our family], in order for her to say that....

President: Yes....

Umuhoza: Maybe even for our child [referring now to Mama Hassan's child, to emphasize they are one family] they were able to do evil (ubugome) to her so that she died. So, for me, that 
thing is where I proceeded from.

When this woman's child unexpectedly died, 'witchcraft' was suspected. Again, misfortune, an unexpected and inexplicable death, brings one to feel the presence of a foreign power, a gift without provenance, and a witch is named. Later, however, Umuhoza came to realize that the witch, in fact, was not the one she initially suspected. Rather the witch was the one (Mama Ishmail) who revealed to Mama Hassan that Mama Hassan’s own relative (Umuhoza) suspected Mama Hassan of witchcraft. However, this newly unmasked witch was not responsible for the death of this woman's child, but rather for that of her relative's child in I994. The malevolence necessary to cause the death of Mama Hassan's child was revealed over a decade later by malicious speech that proved destructive of previously intimate social relations. The same destructive force lay behind the recent act of speaking evil and the distant act of doing evil.

The association of speaking evil words with executing acts of witchcraft was prevalent throughout Rwandan society. When Gravel conducted fieldwork in Rwanda in I960, he noted that "speaking evil of someone is harmful," and referred to "a case in which a woman blamed her husband's sister for the sickness of her child because the husband's sister had spoken ill of the child” (I968: I46). And, notably, as in both that case and Mama Hassan's, witcheraft accusations often marked relations between affines, particularly female ones, within the context of patrilineal descent and patrilocal marriage (see Wilson I95I). In another context, I once asked an elderly Rwandan interlocutor who was discussing witcheraft accusations what would alert someone to suspect another of being a witch, and he replied: 'Those things were caused by bad words. When one said bad words, they would say that (s)he is a witch (umurozi).'

In the Gacaca narrative, bad words and acts of witcheraft were understood as different outward manifestations of the same internally located capacity to commit evil. This power had the force of compulsion, in that it drove Mama Ishmail into anti-social acts, both great and small, for no other reason 
than simply to commit evil. This force, as we saw in Mama Hassan's narrative, transcended discrete subjects to operate along familial lines, compelling Mama Ismail's daughters to victimize the innocent Hassan. If we can tie this imagined power to the one described by the two young men, whose formulations were interpellated by state discourses on genocide ideology, its ability to operate independently of particular subjects can be seen to extend even as far as the ethnic group, where it becomes a new menace of even greater proportions, namely, the destructive capacity of Hutu. That is, genocide ideology, following witchcraft, came to operate according to a local logic of contagion (cf. Fujii 2009: 99-I02)—of which the 'curse' (umuvumo) was one named form—polluting, as we have seen, along lines of spatial as well as genealogical proximity and across great temporal distance. Such a hermeneutic constituted a form of chronotopic leakage — a wide latitude in identifying the locus of threat, its spatio-temporal bleeding along multiple lines of transmission — which amplified the paranoid readings that drove it, via a hypertrophied or schizmogenic response (Geraghty 2016). Critically, this hermeneutic was also a potential condition of possibility for genocide, constituting the boundaries of an enemy upon the overlapping of genealogical and socio-spatial intimacy. And yet here it was being furthered, rather than targeted, by the New Rwanda's campaign against genocide ideology, inscribing the latter into a relationship of continuity rather than rupture with the Genocide of 1994, when (amongst many other critical dynamics) this local hermeneutic came to be coopted and transformed through a cataclysmic state project of ethnic extermination.

That Umuhoza could accuse another of being a witch, without thereby revealing herself to be one, owed less to any "belief" or acceptance of what she was saying and more to the fear of being accused of genocide ideology, as the very transformation of witchcraft. Just after she spoke, one man, who was locally recognized as Tutsi and thereby afforded a greater ability to speak, began to point out that there were 'ordinary conflicts' motivating Umuhoza's testimony. He was immediately silenced with accusations of committing gushinyagura against the mother of the dead child, by both the President of the court and the overall President of Gacaca for this region (umurenge), who was sitting among the 'ordinary people' in 
attendance. Earlier in the trial, when Mama Ishmail had tried to narrate that Umuhoza was the 'driving force' (umurego) behind the case against her family, this same regional President, who had appointed himself to create the case files for those who were to be tried, silenced her with a direct threat: 'If there is certain information that she [Umuhoza] gave us, she [Mama Ishmail] should not hold it against her. And even to continue to act like this, makes clear she [Mama Ishmail] is trivializing genocide (gupfobya jenoside)... We are going to make a dossier (dosiye) for those things and we will charge her with them.'

Accusations of trivializing genocide, genocide ideology, or committing gushinyagura against the victims commonly met those defending the accused in Gacaca. Even when not explicitly invoked, such accusations haunted the ways in which people spoke as well as the pervasive silences of the vast majority of those in attendance. This produced another great contradiction of Gacaca: in the guise of 'allowing the ordinary people to speak,' it came to operate as a strategy of silencing. In less public spaces beyond the trial, within the circulations of hearsay among those critical of Gacaca, who included genocide survivors and other Tutsi opposed to these courts, accusations of genocide and genocide ideology were returned to the more mundane hatreds, petty conflicts, and the endemic "corruption payments" or 'fealty tributes' (uruswa) felt to motivate them.

For its part, the Gacaca court did not deny that there were mundane conflicts between these families. However, its entire modus operandi was dedicated to seeing something more in such interactions. The magical modes of divination-in the sense theorized by Siegel, following Mauss, of a copula tying two otherwise unrelated and unrelatable elements—used by those who reported their neighbors for genocide to Gacaca, paralleled the hermeneutical practices of the courts themselves, where every single sign either came to be suspect or rendered excessively meaningful, allowing a wide range of inferences and connections in ways that for the court were marked by paranoia. The Gacaca court became engaged, uncannily, in translating seemingly mundane events onto a completely different register, in which they were seen to be possessed by something altogether alarming. 


\section{GuSHINYAgURA, TRAUMA, REPETITION}

Gahutu's role in the death of his neighbor's child only became visible to the court after his family was alleged to have committed an act of gushinyagura. Although this charge was used to justify his retrial, the court never clearly specified what his family had done, other than one incident it introduced only tangentially. Hitherto, the President had been placing all the blame upon Mama Ishmail for this act, and he used a distinctly gendered term for the 'cries of celebration' (impundu) he was condemning. Yet, when seemingly exasperated with her continued rejection of the charge, he abruptly changed tack and confronted her with a new challenge:

President: Do you not have a son who rides a motorbike?

M. Ishmail: I do but...

President: [interjecting] So how do you think I got to know about him? For me [addressing the people in attendance], what I know is that it was my first time to see them [saying he did not know Gahutu's family before the trial]. But really that son, the motorist, he came swerving on the moto in front of these people who lost (batsinzwe). Swerving around a lot! And he said, 'Papa I can put you on the moto and take you.' Those people were cut off and couldn't find a way to pass. These things come back!

So now the problem lies with the son, another indication that Gahutu was being tried for the "crimes" of his family, as its head (contra the principle of crime as individual within the writ of both Gacaca and Rwandan civil law). In this area, a motorbike was a sign of wealth, even though Gahutu's son had merely temporarily performed a taxi service for its owner. According to the President, after the court had sentenced Gahutu, his son had swerved his motorbike on the road in excitement, wanting to give his father a ride in an apparent victory celebration. The victims in the case had their path blocked by the son, his motorbike, and his conversation with his father, and abruptly confronted with the celebrations, and 
prosperity, of people they had publicly revealed were their enemies yet failed to imprison, they were humiliated and were reminded of their now double 'loss.' For the President was claiming that such displays of victory and prosperity by those accused of genocide, at the expense of the survivors, resulted in a repetition of the traumatic effects of the Genocide upon the latter. Subject to the scrutiny of the Gacaca court, everyday interactions between persons differentiated as "Hutu" and "Tutsi" were always overdetermined. Many lines of convergence were brought to bear upon a single act, inscribing it with the unbearable weight of a horrific history, which called for its violence to be reciprocated and endlessly repeated.

'These things come back,' the President ominously warned her. Causing suffering to genocide survivors would have consequences - it would be subject to another form of repetition by the court, which placed itself in the position of the traumatized subject. Gacaca would intervene to punish present-day acts that not only menaced Tutsi but even 'disrespected' (gusuzugura) them or 'inverted the rightful hierarchical relation' of Tutsi with respect to Hutu, just as it punished atrocities committed in I994. It would seek to reverse the 'loss' suffered by the "victims" by returning it to those being made to stand in for Hutu perpetrators (seemingly of "the Genocide," even though Gahutu had been acquitted of the genocide charge brought against him by these same victims). The Gacaca court acted as a stage for reenactment, an effort at redemption through repetition-with the difference that it could now subject violence and humiliation to the other side - in an effort to master its own trauma. Acts and utterances in the present that caused pain to survivors indexed the continuing Hutu threat to menace or humiliate Tutsi, which for the court precisely constituted the crime of genocide.

Thus, the crime of genocide could not simply have its energy bound to the period of 1990-1994. This was why so many who identified with the New Rwanda at the time of my research continued to emphasize that the Genocide had not ended, but 'still continues,' pointing out to me the 'hate-filled' acts and utterances of their neighbors as evidence. For the court, the present-day act of gushinyagura had a relation 
of equivalence, structured by iterability (Derrida 1977), with the crime of genocide: the former stood as an iteration, or a repetition-in-difference, of the latter. While in the realm of written law gushinyagura was distinguished from crimes committed in 1994, in practice it became yet another instance of what, for the state, was the phenomenon of genocide ideology — a fetish whose presence constituted all acts in which it was detected as "genocide." Acts of genocide ideology became but a repetition of-or were subject to the iterability of - "the Genocide." Genocide thus was not a singular event or crime consigned to the past, but an on-going phenomenon that it was precisely the responsibility of the court to arrest-paradoxically, by repeating - its continued repetition in new forms and contexts. Gacaca sought to do so by divining hidden potentialities in the past, even if they had not reached the level of actualization; potentialities that could be made visible through revelations in the present. As an iteration of the crime of genocide, the act of gushinyagura revealed that Gahutu was guilty of genocide, that his family was possessed by a lethal compulsion to menace Tutsi. It was a repetition, however, that preceded the "original" act itself, which it therefore retroactively actualized, or performatively enacted, in the very process of its / repetition. Once Gahutu is determined to be possessed by this capacity, rendering him guilty of genocide, he must be eliminated through imprisonment in an effort to not only redeem the past but safeguard the future.

\section{GUILT, REPENTANCE, REVOLUTION}

In court, the President never specified whether he had witnessed the motorbike scene or had merely heard about it. Constantly obscuring the sources of their knowledge and modes of surveillance, the panoptic power and terror of these courts derived in part from their secrecy and ambiguity. Such lacunae were central to how these courts produced and validated their narratives. The President made a claim for the veracity of the evidence he was presenting by arguing that it was only through the motorbike incident that he came to learn that the accused and his wife had a son who rode a motorbike. Given that he now knew 
this, the "truth" of the event was thereby demonstrated and indisputable. So, while evidence was cited in these public performances of truth, it could come from unknown, unverifiable, and unchallengeable sources, backed by the power and authority of the court. The President did not go into any analysis of the motorcycle incident. He raised it to remind Mama Ishmail that she could not continue to deny her family's guilt and should stop challenging the court. From the outset, the guilt of the family of the accused was known, illustrating that Gacaca, like other legal spectacles of sovereign power of the New Rwanda (see Mwambari 2019: I0), were not actually about adjudicating guilt. ${ }^{7}$ Rather their task was to reveal, recognize, and name that guilt, while demanding that the accused accept it and perform their repentance.

As Gacaca courts inscribed those brought before them into the social type of the Hutu perpetrator, all efforts by the accused to argue for their innocence were understood as a continuation of Hutu aggression. As continuing enactments of the violent conflict of the past, such acts were deeply problematic, even potentially criminal, which reveals why Gacaca imprisoned so many witnesses for "lying." In addition to gushinyagura, the problem of challenging the court had been raised from the outset in order to justify Gahutu's retrial: 'Then there is another thing: Concerning the pardon we gave people who didn't even want it! Because there are some words that were said: 'Why did they give us a pardon when we didn't even ask for it?' We had a problem with that.' The President was suggesting that the court was deeply troubled to find that their ('lenient') sentencing was accorded neither appropriate respect nor quiet acceptance.

Critically, in Rwanda, 'asking for a pardon' (gusaba imbabazi), or rather 'begging for mercy,' was understood as placing the penitent in a subservient position to the authority being supplicated. It was a performance of respect for rightful hierarchy. This 'natural(ized) inequality' (cf. Maquet I96I) was not merely interpersonal but extended from the fundamental social division continuously re-inscribed by these courts - between Hutu perpetrators and Tutsi victims - all the way up to the authority of the state itself, which was seen as the ultimate determinant of status relations between Hutu and Tutsi. Throughout the retrial, the President continually accused Gahutu's family of 'refusing to show humility' or 'lower 
themselves' (ntibicishije bugufi), which was thus not merely before genocide survivors but also the institution of the state, which positioned itself as their protector. Mama Ishmail's defense of her family in court was then read as a continuation of this deep disrespect for the authority of the court. When she responded to the President that she had not been with her son at the time of the motorbike incident, he issued her a direct threat: 'Mama Ishmail, don't keep standing your ground (ntukihagarareho). Because those things will bring you trouble (ingorane), if not here, then elsewhere.'

Protesting one's innocence, that is, denying one's guilt in contradiction to assertions of the court, was, whatever the basis of the charge, a serious problem which would demand redress, if not within Gacaca then perhaps through prosecution for genocide ideology in the regular courts. The demand that persons being tried ritually perform their submission and repentance, even for crimes that they had not been convicted of and acts that were legally not even crimes, both in their everyday lives before "survivors" and before Gacaca, reveals how these courts were interested in something other than confessions of responsibility for crimes committed in 1994. That is to say, if Gacaca operated as an instrument of revenge, it was engaged in exacting vengeance not primarily for the 1994 Genocide or its survivors, but rather for the 1959

\section{Revolution and its elite Tutsi victims.}

The 1994 state-sponsored, systematic extermination campaign against Rwanda's internal Tutsi population came at the culmination of a four-year war launched by the RPF rebel forces to capture the Rwandan state. This politico-military formation was founded by those who prior to 1994 had lived in exile-descendants of those who had been expelled from the country, as the hitherto ruling Tutsi elite, through a series of violence events retroactively inscribed by the regimes founded upon them as the I959 "Hutu" Revolution. This Revolution had been discursively constructed as 'overturning centuries of oppressive Tutsi rule' to confer a new, democratic, authority upon "the Hutu," long inscribed as the demographic "majority" by colonial technologies of governmentality (bureaucratic surveillance, classification, standardization, quantification, systematization, etc.). For the RPF, this new social and 
political force, unleashed via a virulent discourse of ethnicity, overturned the rightful "traditional" "Rwandan" authority. Thus, the demand for Hutu to 'lower themselves' before "genocide survivors" and the institutions of the New Rwanda that claimed to champion them was understood precisely as the reassertion of the right order of things that had prevailed during the "precolonial tradition" invoked by Gacaca’s self-legitimating narrative.

Critically, in unofficial, everyday discourse, the former exiles who dominated the RPF positioned themselves as the descendants of Rwanda's colonial and precolonial 'aristocracy,' in contradistinction to non-exiled, lower-status Tutsi (derogatorily labeled "uncivilized" sopecya, at least up to the time of Gacaca), who were victims of the 1994 Genocide yet, at the time of Gacaca, remained relatively marginalized within the New Rwanda, 'tainted' by decades 'mixing' and living under 'Hutu rule.' The RPF's 'Victory' (Intsinzi) in I994, inaugurating the New Rwanda, was understood as having 'vanquished' the 1959 Revolution discursively constituting the latter as a purely destructive event responsible for unleashing a period of unprovoked violence against Tutsi. Once the term "genocide" was established in Rwandan political vocabulary after 1994, those tied to the RPF began propagating the discourse that the Genocide had begun in I959. Thus, the I994 Genocide was but an iteration of the force responsible for 1959, an event which itself came to be retroactively inscribed, post-I994, as "genocide," indeed as the very inception of the "Genocide Against the Tutsi." Since acts of genocide ideology were but a repetition ofor were subject to the iterability of - the Genocide, "genocide ideology" named that destructive democratic force first unleashed in 1959, inaugurating Genocide (Geraghty 2016). This was why at the outset of the retrial the President already posed the question of gushinyagura as a 'return' to the problem of genocide and why it was understood as an iteration of genocide. This force continued to manifest itself in the failure of those inscribed as "Hutu" to recognize the right order of things and perform their rightful (naturalized) "traditional" subservience to Tutsi. While Genocide allowed both 1959 and the New Rwanda to be articulated, Genocide became a fetish substitute for 1959, rendering post-I959 Rwandan Tutsis, or 
genocide survivors, surrogate victims for exiled Tutsi victimage in 1959. Genocide allowed formerly exiled Tutsi to supplant their body doubles and take their rightful place. It was this that made Rwandan Tutsi (or genocide survivors) so problematic after 1994, as anachronisms in the New Rwanda. And it was why the formerly exiled Tutsi leaders of the New Rwanda, who were never targeted by the I994 Genocide, were nevertheless so obsessed with it, while at the same time capable of exercising continual disregard for the plight of genocide survivors.

Like all other institutions of the New Rwanda, Gacaca was actively engaged in ensuring that all signs that came under its scrutiny performatively re-inscribed, or were subject to the iterability of, the RPF Victory. As this violent founding moment of the new state was understood to have spelled the end of the Hutu dominance promised by the Revolution, within Gacaca the only acceptable role for those it marked as "Hutu" was to continually perform humility, submission, or 'defeat.' For Gahutu's family to attempt to celebrate as though "they" were the 'victors' thus was not merely problematic for marginalized genocide survivors but deemed a threat to the state itself. Mama Ishmail's refusal to accept her family's guilt was a refusal to accept that their side, the Hutu, had lost. Her acceptance of 'being defeated' (baratsinzwe - the same verb as 'victory' [intsinzi], highlighting that their 'defeat' was our 'victory,' and vice versa) would have substituted for the 'defeat' or 'loss' (batsinzwe) suffered by the victims, which the President kept referring to. For those marked as "Hutu" to mock either the decisions of an institution critical to the new state's mode of exercising power, or "genocide survivors," who metonymically stood for all Tutsi to a state founded on appropriating their suffering, betrayed either continued allegiance to the former "Hutu" state or the recognition of one to come. To the state, such acts constituted performatives of "law-founding" violence (Benjamin 1997; Derrida 2002). Thus, the threat they were felt to pose was far greater than any ordinary crime, and indeed the category of "crime," we can now see, was not applicable to such a conception of genocide.

If the Gacaca court, as a state institution, placed itself in the position of the traumatized subject and 
was compelled to continually reenact the same mythical conflict of Hutu aggressor and innocent Tutsi victim, the "originary" traumatic event or structure it was bound to repeat was not that of the I994 Genocide but rather the 1959 Revolution. The figure of the 'intransigent' (impirimbanyi) Hutu was associated with the suspected continued adherence, by opposition Hutu politicians-prior to the banning of the opposition "Hutu" MDR party for genocide ideology in 2003-to the 'principles' of the I959 Revolution. This figure marked the 'obstinate refusal' to recognize the RPF's Victory-its own "revolution" or Liberation (Kwibohora)—as overturning the now illegitimate 'mayhem' (imvururu) of 1959. This figure appeared (from I998) at the same moment that genocide ideology or its precursors were born as a national threat (Geraghty 2016). Gacaca drew upon this figure-previously limited to educated Hutu elites - to conjure the spectral threat of 'ordinary citizens' "harboring" genocide ideology, undermining the new state from below. Gacaca was also able to draw upon the discourse propagated even by foreign-based academics that the "post-genocide" Rwandan state presided over a "criminal population" (Mamdani 200I: 6-7, passim), which for the RPF meant an insurrectionary population. Such a paranoia involved projection, creating an interiority within 'others,' hidden just below the surface, always ready to erupt — the very criminal interiority officially named "genocide ideology." Part of Gacaca's project was precisely to manage such a threat, and through its practice it rendered all those it marked as "Hutu" potentially "criminal," capable of law-founding violence. All acts and utterances that failed to reiterate or performatively enact the defeat of "Hutu" rule came to mark one as "Hutu," now transformed into a negative political category, where such negativity was partially dislodged from the identity project of an ethnic group. While Gacaca had the effect of re-inscribing the primacy of ethnic difference within the New Rwanda, it transformed the meaning of those categories. "Hutu" came to signify "Interahamwe," or 'genocide killer,' and yet through the relay of "I959," such negative semantic content was returned back to the ethnicity "Hutu." Gacaca thereby rendered "Hutu" a spectral menace that threatened the very existence of the "new" nation-state. 
Thus, the lethal capacity of the witch, for which Gahutu's neighbors sought to report his family to Gacaca, came to be paranoically substituted by the court with another foreign power- the feared, immanent energies of a destructive collective, their imagined capacity for revolutionary violence, a performative force that conjured the specter of a future Hutu state. The anti-social power of the witch thereby came to be translated by Gacaca into a pervasive and continuing destructive potential aimed at Tutsi, who were taken as metonymic of the new state. Genocide, thus, could not be conscribed to acts assigned to the past but represented a force that continued to operate within the country and constantly threatened to disrupt the future, the present, and the past. The translation of witchcraft into genocide through the practice of Gacaca transformed witchcraft from a non-ethnic, local-level phenomenon between social intimates into an ethno-national menace, which the state itself felt threatened by and sought to act against. From the limited perspective of the state, Gacaca’s attempts to prosecute genocide-its divination of a revolutionary performative force within present-day acts and utterances, followed by the naming of that force as genocide ideology (as the interiority that compelled one to commit acts of genocide), leading to the imprisonment of all those associated with it-became an attempt to purge the presence of this felt menace from the nation-state in an effort to safeguard its very foundation. Once this force came to be identified, through the paranoid projections of the court, in the post-acquittal 'celebrations' of Gahutu's family, it necessitated that he-as a substitute for his family and as a momentary instantiation of the spectral figure of the "Hutu"-be retried and convicted for a "crime" that prior to his family's act(s) of gushinyagura (or 'mocking') was non-existent. Thus, by the end of the re-trial the Gacaca court sentenced Gahutu to fifteen years in prison. Justice came to be served to a man whom those who organized Gacaca trials locally subsequently came to refer to as one of the great "Interahamwe," or 'genocide killers,' of the neighborhood. 


\section{REFERENCES}

Adorno, Theodor. 2010. Guilt and Defense: On the Legacies of National Socialism in Postwar Germany. Cambridge: Harvard University Press,.

Amin, Shahid. 1995. Event, Metaphor, Memory: Chauri Chaura, I922-1992. Berkeley: University of California Press.

Austin, John. 1962. How To Do Things With Words. Oxford: Oxford University Press.

Benjamin, Walter. 1997. "Critique of Violence [1921]." In Selected Writings, edited by Bullock and Jennings. Vol. I. New York: Belknap, Harvard.

- 2006. Selected Writings. Edited by Jennings and Eiland. Vol. 4. New York: Belknap Harvard.

Blanchot, Maurice. 198I. "The Narrative Voice." In The Gaze of Orpheus, and Other Literary Essays. Barrytown: Station Hill Press.

Chakravarty, Anuradha. 2016. Investing in Authoritarian Rule: Punishment and Patronage in Rwanda's Gacaca Courts for Genocide Crimes. New York: Cambridge University Press.

Chanock, Martin. 1985. Law, Custom, and Social Order: The Colonial Experience in Malawi and Zambia. Cambridge: Cambridge University Press.

Clapham, Christopher. 1998. African Guerrillas. Oxford: James Currey.

Comaroff, Jean, and John Comaroff. 2012. "History on Trial: Memory, Evidence, and the Forensic Production of the Past." In Theory from the South, I33-52. Boulder: Paradigm Publishers.

Comaroff, John. 200I. "Colonialism, Culture, and the Law.” Law \& Social Inquiry 26 (02): 305-I4.

Corey, Allison, and Sandra Joireman. 2004. "Retributive Justice: The Gacaca Courts in Rwanda." African Affairs 103 (4I0): 73-89.

Derrida, Jacques. 1977. Limited Inc. Evanston: Northwestern University Press.

- 2002. "Force of Law: The 'Mystical Foundation of Authority."' In Acts of Religion, edited by Gil Anidjar. New York: Routledge.

Doughty, Kristin. 2016. Remediation in Rwanda: Grassroots Legal Forums. Philadelphia: University of Pennsylvania Press.

Feldman, Allen. 2015. "Traumatizing the Truth Commission." In Archives of the Insensible: Of War, Photopolitics, and Dead Memory. Chicago: University of Chicago Press.

Felman, Shoshana. 2002. The Juridical Unconscious: Trials and Traumas in the Twentieth Century. Cambridge: Harvard University Press.

Fields, Karen. 1985. Revival and Rebellion in Colonial Central Africa. Princeton: Princeton University Press.

Foucault, Miche1. 2003. Society Must Be Defended: Lectures at the College de France, 1975-76. Edited by Fontana and Bertani. New York: Picador.

- 2014. Wrong-Doing, Truth-Telling: The Function of Avowal in Justice. Edited by Brion and Harcourt. Chicago: University of Chicago Press.

Fujii, Lee Ann. 2009. Killing Neighbors: Webs of Violence in Rwanda. Ithaca: Cornell University Press. 
Geraghty, Mark Anthony. 2016. "Genocide Ideology, Nation-Building, Counter-Revolution: Specters of the Rwandan Nation-State.” Doctoral Dissertation, ProQuest: University of Chicago.

Getty, Arch, Oleg Naumov, and Benjamin Sher. 20I0. The Road to Terror: Stalin and the Self-Destruction of the Bolsheviks, 1932-1939. New Haven: Yale University Press.

Gravel, Pierre Bettez. 1968. Remera: A Community in Eastern Ruanda. Paris: Mouton.

Henderson, Jennifer, and Pauline Wakeham, eds. 2013. Reconciling Canada: Critical Perspectives on the Culture of Redress. Toronto: University of Toronto Press.

Hobsbawm, E. J., and T. O. Ranger. 1983. The Invention of Tradition. Cambridge: Cambridge University Press.

Hodos, George H. 1987. Show Trials: Stalinist Purges in Eastern Europe, 1948-1954. New York: Praeger.

Hofstadter, Richard. 1965. The Paranoid Style in American Politics and Other Essays. New York: Knopf.

Humphrey, Michael. 2003. "From Victim to Victimhood: Truth Commissions and Trials as Rituals of Political Transition and Individual Healing." Australian Journal of Anthropology I4 (2): I7 I-87.

Ingelaere, Bert. 2016. Inside Rwanda's Gacaca Courts: Seeking Justice after Genocide. Madison: University of Wisconsin Press.

Kagame, Alexis. 1969. Introduction Aux Grands Genres Lyriques de l’ancien Rwanda. Butare: Éditions universitaires du Rwanda.

Madley, Benjamin. 2016. An American Genocide: The United States and the California Indian Catastrophe, I846-I873. New Haven: Yale University Press.

Mamdani, Mahmood. 2000. "The Truth According to the TRC.” In The Politics of Memory: Truth, Healing and Social Justice, edited by Amadiume and An-Na'im. London: Zed Books.

- 200I. When Victims Become Killers: Colonialism, Nativism, and the Genocide in Rwanda. Princeton: Princeton University Press.

Maquet, Jacques Jérôme Pierre. I96I. The Premise of Inequality in Ruanda; a Study of Political Relations in a Central African Kingdom. London,: Published for the International African Institute by the Oxford University Press.

Merry, Sally Engle, and Susan Bibler Coutin. 20I4. "Technologies of Truth in the Anthropology of Conflict.” American Ethnologist 4I (I): I-I6.

Moodie, Ellen. 2010. El Salvador in the Aftermath of Peace. Philadelphia: University of Pennsylvania Press.

Mwambari, David. 2019. "Music and the Politics of the Past: Kizito Mihigo and Music in the Commemoration of the Genocide against the Tutsi in Rwanda." Memory Studies, February, I-I6.

Nietzsche, Friedrich. 1998. On the Genealogy of Morality. Translated by Clark and Swensen. Indianapolis: Hackett.

Perez, Isaias Rojas. 2008. "Writing the Aftermath: Anthropology and 'Post-Conflict.”' In A Companion to Latin American Anthropology, edited by Deborah Poole, 254-75. Malden: Blackwell Publishing.

Prunier, Gérard. 2009. Africa's World War: Congo, the Rwandan Genocide, and the Making of a Continental Catastrophe. Oxford: Oxford University Press.

Reyntjens, Filip. I990. “Le Gacaca Ou La Justice Du Gazon Au Rwanda.” Politique Africaine 40: 3I-4I. 
- 2013. Political Governance in Post-Genocide Rwanda. New York: Cambridge University Press.

Sedgwick, Eve. 2003. "Paranoid Reading and Reparative Reading." In Touching Feeling, I23-5I. Duke University Press.

Shaw, Rosalind, Lars Waldorf, and Pierre Hazan, eds. 20I0. Localizing Transitional Justice: Interventions and Priorities after Mass Violence. Stanford: Stanford University Press.

Siegel, James. 2006. Naming the Witch. Stanford: Stanford University Press.

Slotta, James. 20I5. "Phatic Rituals of the Liberal Democratic Polity: Hearing Voices in the Hearings of the Royal Commission on Aboriginal Peoples." Comparative Studies in Society and History 57 (I (Jan)): I30-60.

Taussig, Mick. 1989. "Terror as Usual: Walter Benjamin's Theory of History as a State of Siege." Social Text, no. 23: 3 .

Teitel, Ruti. 2008. “Transitional Justice Globalized.” International Journal of Transitional Justice 2 (I): I4.

Theidon, Kimberly. 2014. Intimate Enemies: Violence and Reconciliation in Peru. Philadelphia: University of Pennsylvania Press.

Viola, Lynne. 2017. Stalinist Perpetrators on Trial: Scenes from the Great Terror in Soviet Ukraine. New York: Oxford University Press.

Waldorf, Lars. 2006. "Mass Justice for Mass Atrocity: Rethinking Local Justice as Transitional Justice.” Temple Law Review 79 (I): I-87.

Whyte, Martin King. 1974. Small Groups and Political Rituals in China. Berkeley: University of California Press.

Wilson, Monica Hunter. I95I. "Witch Beliefs and Social Structure." The American Journal of Sociology 56 (4): 307-I3.

Wilson, Richard. 200I. The Politics of Truth and Reconciliation in South Africa: Legitimizing the PostApartheid State. Cambridge: Cambridge University Press. 


\section{ABSTRACT}

This article investigates the violent aftermaths of Rwanda's 1994 Genocide and Liberation war by analyzing its Gacaca Courts, which framed themselves as a "traditional" mechanism of transitional justice. These specialized genocide tribunals, in operation between 2002 and 2012, authorized laypersons to sentence their neighbors to up to life in prison. They passed judgment on almost two million cases, at an official conviction rate of 86 percent. I argue that through their practice, "genocide" came to be constituted as a crime whose contours extended far beyond the boundaries of any international legal definition. It included a wide range of acts, utterances, and inner states, as potentially infinite manifestations of a boundless criminal interiority named "genocide ideology," the necessary 'driving force' behind acts of genocide. Within Gacaca, genocide ideology was constituted as the continuing destructive potential of Hutu to menace or even disrespect innocent Tutsi, who were constituted as metonymic of the "new" state. The paranoid hermeneutics of those trials led them to project such an interiority within 'others,' imagined as constantly on the verge of erupting into insurrectionary violence, threatening the state's very foundation. The figure of the "Hutu" was transformed into a negative political category operating as a spectral threat haunting the New Rwanda. Gacaca led to a realization throughout the vast population that it marked as "Hutu" that the crime of genocide could potentially inhabit any and perhaps even all of them, thereby producing a generalized fear and pervasive silence.

Key words: Gacaca, genocide, genocide ideology, violent aftermaths, law-founding violence, revolution, the New Rwanda, witchcraft 
Dedication: In memory of Kizito Mihigo (I98I-2020) who survived the Genocide in 1994 only to become the latest victim of its continuing aftermath. Ntidukwiriye kwibagirwa Intwari nyazo zarokotse Jenoside, nyuma zikamburwa ubuzima n'abihaye izina ry'ubutwari.

Acknowledgments: I am indebted to Constantine Nakassis and Rihan Yeh for their incisive comments on an early draft of this paper.

${ }^{\mathrm{I}}$ I use single quotation marks for my translations or glosses of Kinyarwanda language terms, and double quotation marks for direct quotes or when voicing a discourse other than my own. For those terms that circulate widely in Rwanda in both languages, including official state translations, I use double quotes for both versions.

${ }^{2}$ The latter is based on what I was told secretly by Inyangamugayo, local government leaders, and RPF members. Because people were routinely coerced into joining the party, many members did not see themselves as aligned with its interests.

${ }^{3}$ Chakravarty is an exception, led by her normative and comparative approach to "authoritarianism" (2016: I72ff.).

${ }^{4}$ This is contra Chakravarty's liberal assumption that self-consciously rationalizing and self-maximizing Rwandan actors could seamlessly trade submission for safety (2016: 6, passim).

${ }^{5}$ This is contra Doughty's characterization of an almost liberal ideal of "active debating," "broad participation," and "minimal hierarchy" (2016: 9, 13, 2I, passim). Though Gacaca courts were sites of vociferous verbiage, like illiberal trials elsewhere (Hodos 1987; Getty, Naumov, and Sher 2010), which could give Westerners the impression of "vigorous debate," there were great constraints on who could speak and what could be said, which in the New Rwanda, under the specter of genocide ideology accusations, characterized all public fora (Geraghty 20I6).

${ }^{6}$ It did so, through very peculiar "felicity conditions" (Austin I962), which not only presupposed a 
speech act took place, and where the perlocutionary uptake (that the addressee or overhearer was offended as Tutsi) determined that an illocutionary act happened (genocide ideology/speech), but also that, as a performative, this stipulated or entailed by presupposition that the speaker had a certain intention or malice-a supposition that corroborated, circularly, the perlocutionary uptake.

${ }^{7}$ Ingelaere, by contrast, interprets Gacaca as involving "an almost systemic tendency to find a defendant guilty" (2016: 5). 